Murtalim ${ }^{1)}$, Amir ${ }^{2)}$, Sukarman, ${ }^{3)}$ Karyadi ${ }^{4)}$, Agus Supriyanto ${ }^{5)}$, Khoirudin ${ }^{6)}$, Sugiharto ${ }^{7)}$, Toto Supriyono ${ }^{8)}$, Muhamad Abdika Mafruh ${ }^{9)}$, Fachrizal Ahmad Setiawan ${ }^{10)}$, Amar $^{11)}$

Vol 6 No 1

ISSN : 2541-6995

E ISSN : 2580-5517

\title{
OPTIMASI JUMLAH, POSISI, DAN DIAMETER NOZEL TURBIN PELTON MELALUI ANALISIS QFD DAN UJI EKSPERIMENTAL
}

\author{
Murtalim ${ }^{1)}$, Amir ${ }^{2)}$, Sukarman, ${ }^{3)}$ Karyadi $^{4)}$, Agus Supriyanto ${ }^{5)}$, Khoirudin ${ }^{6)}$, Sugiharto ${ }^{7)}$, \\ Toto Supriyono ${ }^{8)}$, Muhamad Abdika Mafruh 9), Fachrizal Ahmad Setiawan ${ }^{10)}$, Amar ${ }^{11)}$ \\ 1), 2) ,3, 4), 5), 6), 7), 8), 9), 10), 11) Teknik Mesin Universitas Buana Perjuangan Karawang \\ Jalan HS Ronggo Waluyo Karawang Jawa Barat \\ murtalim@ubpkarawang.ac.id ${ }^{1)}$ \\ amir@ubpkarawang.ac.id ${ }^{2)}$ \\ sukarman@ubpkarawang.ac.id ${ }^{3)}$ \\ karyadi@ubpkarawang.ac.id ${ }^{4)}$ \\ agus.supriyanto@ubpkarawang.ac.id ${ }^{5)}$ \\ khoirudin@ubpkarawang.ac.id ${ }^{6)}$ \\ sugih.sugiharto@unpas.ac.id ${ }^{7}$ \\ supriyono.toto@unpas.ac.id ${ }^{8)}$ \\ tm19.muhamadmafruh@mhs.ubpkarawang.ac.id ${ }^{9)}$ \\ tm19.fachrizalsetiawan@mhs.ubpkarawang.ac.id ${ }^{10)}$ \\ tm19.amar@mhs.ubpkarawang.ac.id ${ }^{11)}$
}

\begin{abstract}
ABSTRAK
Penduduk Indonesia belum sepenuhnya mendapat layanan penerangan listrik, terutama yang berada di daerah terpencil dan berada di lereng-lereng bukit, sementara di lokasi tersebut terdapat potensi energi yang cukup untuk mengerakkan turbin air sebagai penggerak generator listrik. Turbin pelton adalah salah satu jenis turbin impuls yang performancenya dipengaruhi oleh debit air, nosel, dan jumlah sudu, atas dasar tersebut penulis menyajikan artikel yang menerapkan metode quality function deployment $(Q F D)$ dan pengujian eksperimental terhadap prototipe turbin pelton di laboratorium Universitas Buana Perjuangan Karawang. Langkah-langkah dalam penelitian ini meliputi studi literatur dan lapangan, perancangan, pembuatan alat uji, pengujian, analisis data, dan kesimpulan. Variasi pengujian berdasarkan pada diameter, posisi dan jumlah nosel terhadap sudu turbin yang berjumlah 12 buah dan berdiameter $150 \mathrm{~mm}$, sedangkan untuk pembangkit listriknya menggunakan generator mini berdaya 350 watt. Hasil pengujian yang diperoleh adalah daya input $\left(P_{\text {in }}\right)$ terbesar dengan nilai 73,6 watt terdapat pada $d_{n} 9 \mathrm{~mm}$ dengan posisi nozel atas dan bawah dan jumlah nozel 2 buah. Daya turbin $\left.\left(\mathrm{P}_{\mathrm{t}}\right)\right)$ terbesar dengan nilai 70,1 watt terdapat pada $d_{n}=6 \mathrm{~mm}$, posisi nosel di atas dan jumlah nozel 1 buah, efisiensi turbin $\left(\eta_{t}\right)$ terbesar dengan nilai 95,4\% terjadi pada $\mathrm{dn}=9 \mathrm{~mm}$ dengan jumlah nosel 1 buah dengan posisi nosel di atas, daya generator $\left(\mathrm{P}_{\text {gen }}\right)$ terbesar 11,7 watt terjadi pada $\mathrm{dn}=9 \mathrm{~mm}$ dengan jumlah nosel 1 buah dengan posisi nosel di atas, effisiensi generator $\left(\eta_{\text {gen }}\right)$ terbesar dengan nilai $17,9 \%$ terjadi pada $\mathrm{dn}=9 \mathrm{~mm}$ dengan jumlah nosel 1 buah dengan posisi nosel di atas dan efisiensi sistem terbesar $\left(\eta_{\text {sis }}\right) 17,1 \%$ terjadi pada $\mathrm{dn}=9 \mathrm{~mm}$ dengan jumlah nosel 1 buah d posisi nosel di atas.
\end{abstract}

Kata kunci: Turbin pelton, quality function deployment $(Q F D)$, pengujian eksperimental 
Murtalim ${ }^{1)}$, Amir ${ }^{2)}$, Sukarman, ${ }^{3)}$ Karyadi ${ }^{4)}$, Agus Supriyanto ${ }^{5)}$, Khoirudin ${ }^{6)}$, Sugiharto ${ }^{7)}$, Toto Supriyono ${ }^{8)}$, Muhamad Abdika Mafruh ${ }^{9)}$, Fachrizal Ahmad Setiawan ${ }^{10)}$, Amar ${ }^{11)}$

Vol 6 No 1

ISSN : 2541-6995

E ISSN : 2580-5517

\begin{abstract}
The Indonesian population has not fully received electric lighting services, especially in remote areas and on hillsides, while there is sufficient energy potential to drive water turbines to drive electricity generators. Pelton turbine is one type of impulse turbine whose performance is influenced by water discharge, nozzle, and some blades, on this basis the author presents an article that applies the QFD method and experimental testing of the Pelton turbine prototype in thelaboratory of Buana Perjuangan University, Karawang. The steps in this research include literature and field studies, design, manufacture of test equipment, testing, data analysis, and conclusions. The variation of the test is based on the diameter, position, and some nozzles for the turbine blades, which are 12 pieces and $150 \mathrm{~mm}$ in diameter, while for the power plant it uses a 350-watt mini generator. The test results obtained are the largest input power $\left(P_{\text {in }}\right)$ with a value of 73.6 watt is found at dn $9 \mathrm{~mm}$ with the position of the top and bottom nozzles and the number of nozzles is 2 pieces. The largest turbine power $\left(P_{t}\right)$ with a value of 70.1 watts is found at $d n=6 \mathrm{~mm}$, the position of the nozzle is above and the number of nozzles is 1, the largest turbine efficiency $\left(\eta_{t}\right)$ with a value of $95.4 \%$ occurs at $d n=9 \mathrm{~mm}$ with a total 1 nozzle with the nozzle position is above, the largest generator power $\left(P_{\text {gen }}\right)$ of 11.7 watt occurred at $d n=9 \mathrm{~mm}$ with some 1 nozzle with the nozzle position is above, the largest generator efficiency $\left(\eta_{\text {gen }}\right)$ with a value of $17.9 \%$ occurred in $d n=9 \mathrm{~mm}$ with the number of nozzles 1 piece with the nozzle position on the top and the largest system efficiency $\left(\eta_{\text {sis }}\right) 17.1 \% \%$ occurred at $d n=9 \mathrm{~mm}$ with the number of nozzles 1 piece with the nozzle position on the top.
\end{abstract}

Keyword: Pelton turbine, quality function deployment ( $Q F D)$ experimental testing

\title{
PENDAHULUAN
}

Dengan keadaan geografis daerah-daerah di Indonesia yang banyak memiliki potensi air dengan head yang memadai untuk pembangkit berskala kecil, maka perlu adanya pengembangan teknologi pembangkit berskala kecil yang biasa dikenal sebagai Pembangkit Listrik Tenaga Mikrohidro (PLTMH), ((Pasalli \& Rehiara, 2014), (Turbin \& Di, 2015)

Potensi energi air di Indonesia dapat mencapai 75.000 MW dan baru $8 \%$ atau sekitar 3700 MW yang telah dimanfaatkan pembangkit listrik tenaga air dan mikrohidro. Pengembangan pembangkit listrik tenaga air sangat bergantung pada lokasi geografis, curah hujan dan daerah resapan. Kondisi ini melibatkan variasi kapasitas pembangkit. Pemerintah Indonesia sedang berupaya untuk meningkatkan kapasitas mikro hidro hingga $2846 \mathrm{MW}$ pada tahun 2025 (Pasalli \& Rehiara, 2014) (Subekti \& Susatyo, 2015)

Pembangkit listrik tenaga air adalah proses non-polusi yang memanfaatkan tinggi air yang mengalir untuk menghasilkan listrik, (Rameez \& Prince, 2015). Turbin air merupakan salah satu alat yang mengubah energi kinetik dari aliran air dengan kecepatan tinggi melalui 
Murtalim 1), Amir ${ }^{2)}$, Sukarman, ${ }^{3)}$ Karyadi ${ }^{4)}$, Agus Supriyanto ${ }^{5)}$, Khoirudin ${ }^{6)}$, Sugiharto ${ }^{7)}$, Toto Supriyono ${ }^{8)}$, Muhamad Abdika Mafruh ${ }^{9)}$, Fachrizal Ahmad Setiawan ${ }^{10)}$, Amar ${ }^{11)}$

Vol 6 No 1

ISSN : 2541-6995

E ISSN : 2580-5517

lubang nosel yang menyemprotkan air tepat pada sudu-sudu turbin sehingga menghasilkan energi mekanik berupa putaran pada runner turbin. Energi mekanik ini kemudian digunakan untuk memutar generator dengan cara disambung secara langsung atau melalui perbandingan roda gigi,sehingga dapat menghasilkan listrik,(Turbin \& Di, 2015)).

Beberapa penelitian telah dilakukan mengenai turbin pelton, salah satunya adalah perencanaan turbin air mikrohidro jenis pelton yang hanya memiliki variable head, salah satu tujuan penelitianya adalah penulis ingin mengembangkan alat uji turbin pelton yang sedikit berbeda dengan penelitian yang dilakukan sebelumnya, kali ini penulis ingin menganalisa secara $Q F D$ dan kajian eksperimental mengenai pengaruh diameter, jumlah dan posisi nosel terhadap daya dan effisiensi turbin pelton. Untuk kedepannya, alat ini digunakan sebagai alat uji praktikum mesin konversi yang terdapat di Laboratorium outdoor Universitas Buana Perjuangan Karawang yang lokasinya berdekatan dengan sumber air dari Curug Cigentis Desa Mekar Buana Tegalwaru Karawang.

Ada beragam jenis turbin yang dapat dipilih untuk pembangkit listrik berdasarkan besarnya head yang tersedia dan beberapa kondisi lain yang tergantung pada air. Pembangkit listrik tenaga air diklasifikasikan dalam berbagai cara seperti total head air yang tersedia di reservoir, kapasitas penyimpanan air di bendungan, daya yang dihasilkan, total head air di reservoir, sifat beban listrik pada pembangkit listrik. Salah satu klasifikasi pembangkit listrik yang paling populer adalah menurut jumlah daya yang dihasilkan seperti yang terdapat di bawah ini (Rameez \& Prince, 2015) (Syarif et al., 2019)

Tabel 1. Klasifikasi Pembangkit Listrik Tenaga Air

\begin{tabular}{cc}
\hline Tipe & Kapasitas $(\mathrm{kW})$ \\
\hline Pico Hidro & $<5$ \\
\hline Mikro Hidro & $6-100$ \\
\hline Mini Hidro & $101-2.000$ \\
\hline Small Hidro & $2.001-25.000$ \\
\hline Large Hidro & $\geq 25.000$ \\
\hline
\end{tabular}

Pada Saat pancaran air dari nosel mengenai turbin, menghasilkan daya poros yang terhubung ke generator listrik yang kemudian menghasilkan tenaga listrik sistem ini dapat digabungkan dengan perangkat penyimpanan daya yang mengumpulkan daya kecil yang 
Murtalim 1), Amir ${ }^{2)}$, Sukarman, ${ }^{3)}$ Karyadi ${ }^{4)}$, Agus Supriyanto ${ }^{5)}$, Khoirudin ${ }^{6)}$, Sugiharto ${ }^{7)}$, Toto Supriyono ${ }^{8)}$, Muhamad Abdika Mafruh ${ }^{9)}$, Fachrizal Ahmad Setiawan ${ }^{10)}$, Amar ${ }^{11)}$

Vol 6 No 1

ISSN : 2541-6995

E ISSN : 2580-5517

dihasilkan sistem. Pembangkit listrik tenaga air Pico hidro ini paling baik digunakan untuk keperluan rumah tangga yang sangat ringan.

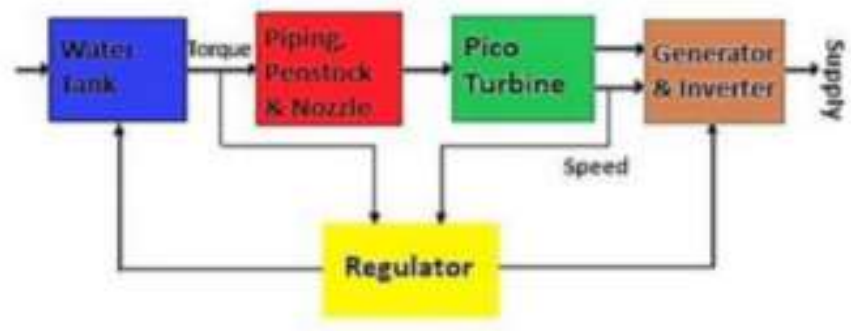

Gambar 1. Diagram skema pembangkit listrik sistem Pico Hydropower (Rameez \& Prince, 2015)

Ada empat parameter yang paling relevan dalam desain turbin, yaitu head bersih $\left(\mathrm{H}_{\mathrm{n}}\right)$, laju aliran $(\mathrm{Q})$, kecepatan rotasi turbin $(n)$ dan efisiensi turbin $(\eta)$. Dua parameter ini $\left(H_{n}\right.$ dan $Q$ ) adalah studi hidrologi data sumber air. Setelah karakteristik aliran, ketinggian atau elevasi di atas permukaan air dari turbin diketahui, , maka dapat melakukan perhitungan dasar untuk menentukan jenis turbin yang akan diterapka(Ebhota \& Inambao, 2016).

Turbin Pelton adalah salah satu turbin impuls yang paling efisien (Poea et al., 2013) dan telah mempertahankan fungsi keberadaannya di pembangkit listrik tenaga air selama lebih dari satu abad (Židonis \& Aggidis, 2015)), namun tidak seperti yang dialami oleh turbin reaksi, perkembangan turbin pelton mengalami hambatan karena sifat aliran yang jauh lebih kompleks dari pada di turbin reaksi (Židonis \& Aggidis, 2016)). Kemampuan cepat untuk menilai kinerja prototipe turbin pelton sangatlah penting sebelum membuat model turbin dengan kapasatas dan daya yang lebih besar. Pengujian eksperimental dengan penerapan dimensi sudu, nosel turbin dan kondisi (Aggidis \& Židonis, 2014)

Komponen - komponen turbin pelton yang penting adalah sebagai berikut :

1. Nosel (Nozzle), berfungsi untuk mengarahkan aliran masuk ke sudu, biasanya dapat diatur untuk mengontrol kapasitas aliran yang masuk (Kurniawan.Y, 2017)

2. Runner, bagian pada runner ini terdiri dari beberapa jumlah sudu dan piringan. Pada bagian ini terjadi peralihan energi potensial air yang menumbuk sudu yang terikat pada runner dan merubah energi tersebut menjadi energi mekanik

3. Poros turbin, pada bagian runner turbin terdapat poros turbin yang ditumpu 
Murtalim 1), Amir ${ }^{2)}$, Sukarman, ${ }^{3)}$ Karyadi ${ }^{4)}$, Agus Supriyanto ${ }^{5)}$, Khoirudin ${ }^{6)}$, Sugiharto ${ }^{7)}$, Toto Supriyono ${ }^{8)}$, Muhamad Abdika Mafruh ${ }^{9)}$, Fachrizal Ahmad Setiawan ${ }^{10)}$, Amar ${ }^{11)}$

Vol 6 No 1

ISSN : 2541-6995

E ISSN : 2580-5517

dengan bantalan radial dan bantalan axial.

4. Rumah turbin (casing), bungsi dari rumah turbin ini adalah sebagai tempat utama turbin dan membatasi pergerakan air agar lebih terarah.

5. Generator, alat ini berfungsi merubah energi mekanik dari poros turbin menjadi energi listrik Tenaga mekanis memutar kumparan kawat penghantar dalam medan magnet ataupun sebaliknya memutar magnet diantara kumparan kumparan kawat penghantar magnet permanen (tetap) tidak memerlukan tenaga atau bantuan dari luar untuk menghasilkan daya magnet (berelektromagnetik). Pengukuran generator dapat dilakukan dengan pengukuran tanpa beban ataupun berbeban (Ihfazh et al., 2013)).

6. Sistem Perpipaan : mengalirkan air dari reservoir ke saluran luar menuju rumah turbin dan dari rumah turbin ke pembuangan atau output.

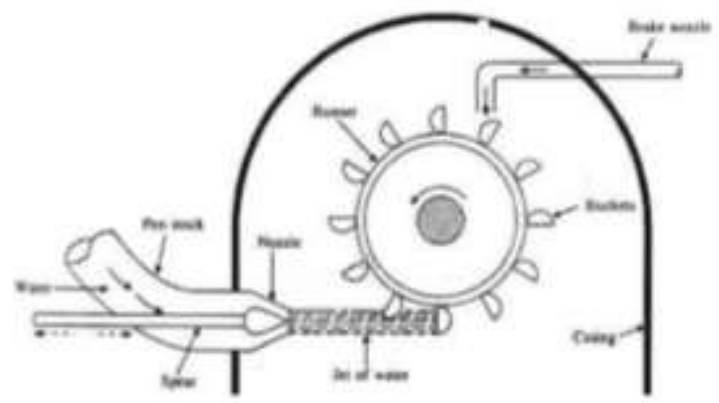

Gambar 2. Susunan Komponen turbin pelton

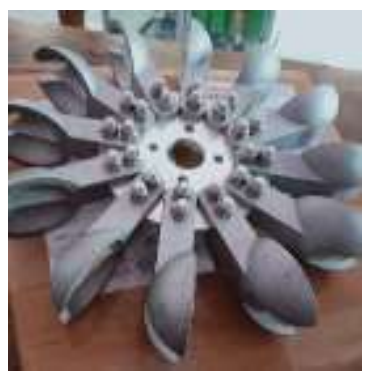

Gambar 3. Runner turbin pelton

\section{METODE PENELITIAN}

Metode penelitian ini di bagi menjadi empat tahapan yang terdiri dari :

1. Tahapan desain, yang dilakukan dengan metode quality funcition deployment (QFD) berupa perancangan instalasi dan komponen turbin pelton dengan menggunakan perangkat lunak $C A D$.
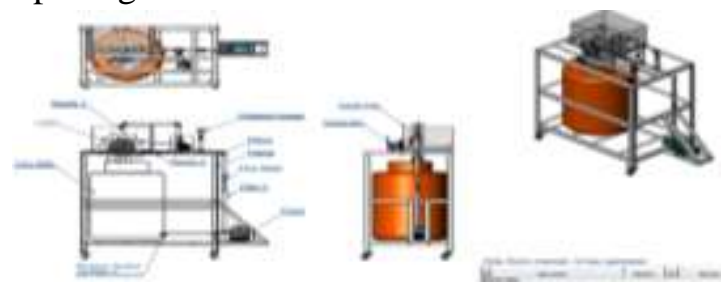
Murtalim 1), Amir ${ }^{2)}$, Sukarman, ${ }^{3)}$ Karyadi ${ }^{4)}$, Agus Supriyanto ${ }^{5)}$, Khoirudin ${ }^{6)}$, Sugiharto ${ }^{7)}$, Toto Supriyono ${ }^{8)}$, Muhamad Abdika Mafruh ${ }^{9)}$, Fachrizal Ahmad Setiawan ${ }^{10)}$, Amar ${ }^{11)}$

Vol 6 No 1

ISSN : 2541-6995

E ISSN : 2580-5517

Gambar 4. Prototipe turbin pelton

2. Tahapan analisis yaitu dilakukan dengan membuat model variasi dari diameter dan jumlah nozel, serta posisi penempatan nozel pada runner atau sudu turbin.

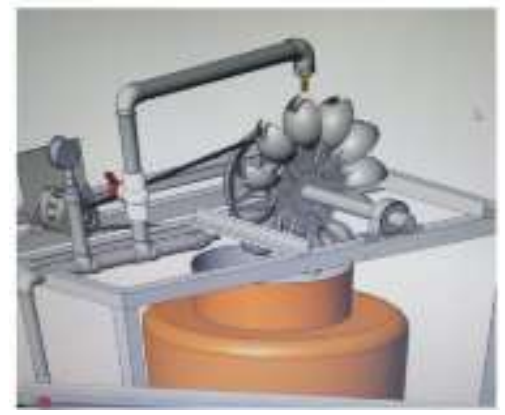

Gambar 5. Variasi diameter, jumlah dan posisi nosel

3. Tahapan ketiga adalah proses manufaktur, dalam tahapan ini adalah tahapan pembuatan dari desain awal yang sudah ada yang kemudian dilakukan proses pengerjaan dan perlakuan dalam proses manufaktur hingga menjadi sebuah produk nyata sebuah pembangkit listrik tenaga air dengan menguanakan turbin pelton berskala laboratorium.

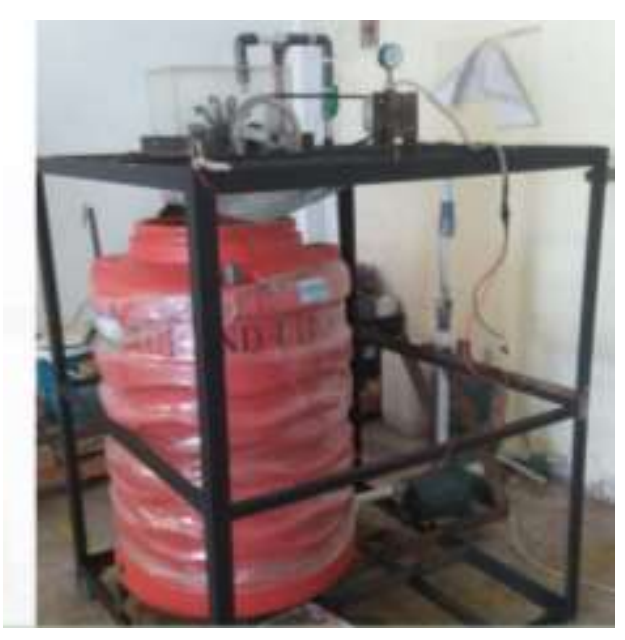

Gambar 6. Turbin Pelton berskala laboratorium

4. Tahapan uji eksperimental, dalam tahap ini akan dilakukan pengujian untuk menentukan variable-variabel yang terdapat dalam menenukan performance dari sebuah pembangkit listrik tenaga air berskala picohidro. 
Murtalim 1), Amir ${ }^{2)}$, Sukarman, ${ }^{3)}$ Karyadi ${ }^{4)}$, Agus Supriyanto ${ }^{5)}$, Khoirudin ${ }^{6)}$, Sugiharto ${ }^{7)}$, Toto Supriyono ${ }^{8)}$, Muhamad Abdika Mafruh ${ }^{9)}$, Fachrizal Ahmad Setiawan ${ }^{10)}$, Amar ${ }^{11)}$

Vol 6 No 1

ISSN : 2541-6995

E ISSN : 2580-5517

Pemilihan jenis turbin dapat ditentukan berdasarkan kelebihan dan kekurangan dari jenis-jenis turbin, khususnya untuk suatu desain yang sangat spesifik. (Sugiri et al., 2013)) Adapun persamaan yang digunakan untuk merancang seuah turbin pelton dapat diperoleh dari grafik di bawah ini yang menunjukan hubungan antara Head dan $n_{s}$ juga jumlah nosel dan kisaran jumlah sudu (D/d) (Singh et al., 2017) (Zhang, 2016)).

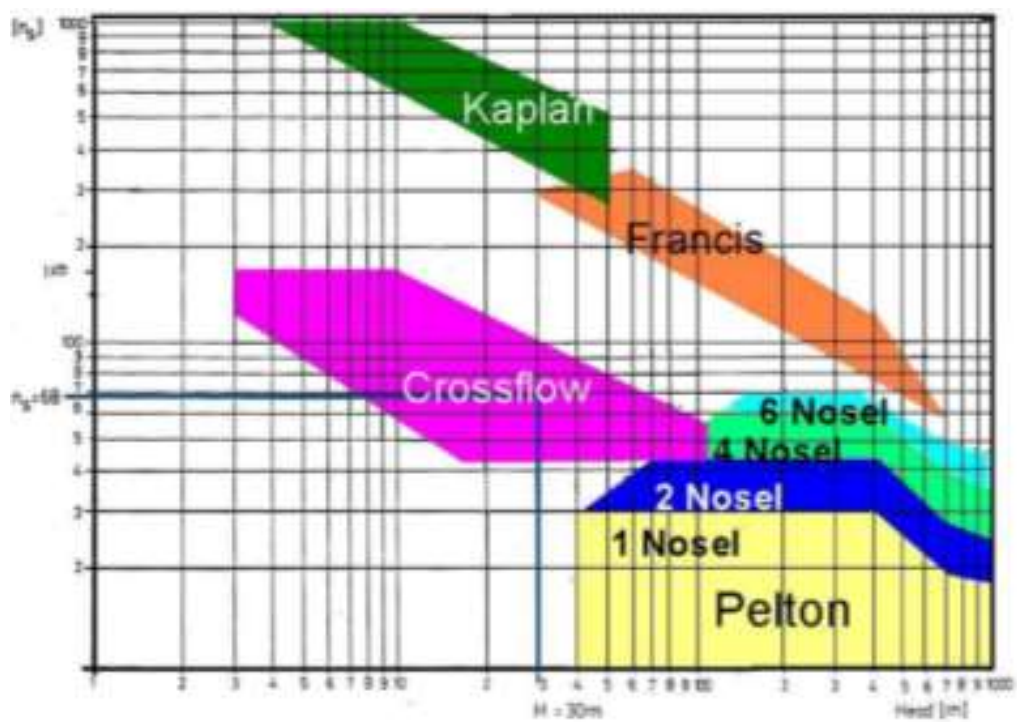

Gambar 7 Kecepatan spesifik $\left(\mathrm{n}_{\mathrm{s}}\right)$ dengan Head $(\mathrm{H})$ (Source : http://indmicrohydro.blogspot.com/)

- Rumus matematis untuk mencari kecepatan spesifik adalah :

$$
\mathrm{n}_{s}=\frac{\mathrm{n}_{\mathrm{t}} \sqrt{\mathrm{Q}}}{H^{\frac{3}{4}}} .
$$

Dimana $: \mathrm{n}_{\mathrm{t}}=$ Putaran turbin rencana $(\mathrm{rpm})$

$$
\begin{aligned}
& \mathrm{Q}=\text { debit fluida }\left(\mathrm{m}^{3} / \mathrm{s}\right) \\
& \mathrm{H}=\operatorname{Head}(\mathrm{m})
\end{aligned}
$$

- Persamaan untuk mencari nosel yang digunakan adalah :

$$
\mathrm{d}_{n}=0,52 \sqrt{\frac{Q}{\sqrt{\mathrm{H}}}} .
$$

Dimana: $\mathrm{Q}=\operatorname{Debit}\left(\mathrm{m}^{3} / \mathrm{s}\right)$

$$
\mathrm{H}=\mathrm{Head}(\mathrm{m})
$$

- Jumlah sudu atau bucket dapat digunakan persamaan : 
Murtalim 1), Amir ${ }^{2)}$, Sukarman, ${ }^{3)}$ Karyadi ${ }^{4)}$, Agus Supriyanto ${ }^{5)}$, Khoirudin ${ }^{6)}$, Sugiharto ${ }^{7)}$, Toto Supriyono ${ }^{8)}$, Muhamad Abdika Mafruh ${ }^{9)}$, Fachrizal Ahmad Setiawan ${ }^{10)}$, Amar ${ }^{11)}$

Vol 6 No 1

ISSN : 2541-6995

E ISSN : 2580-5517

$$
\mathrm{Z}=0,54 \sqrt{\frac{D}{d n}}
$$

Dimana $: \mathrm{D}=$ Diameter runner $(\mathrm{m})$

$$
\mathrm{d}_{\mathrm{n}}=\text { Diameter nosel }(\mathrm{m})
$$

- Dimensi runner

$\mathrm{D}=\frac{60 \mathrm{u}}{\pi \mathrm{n}}$

Dimana $: \mathrm{u}=$ kecepatan keliling $(\mathrm{m} / \mathrm{s})$

$$
\begin{aligned}
& \mathrm{u}=\frac{\pi \cdot D \cdot n_{t}}{60} \ldots \ldots \ldots \ldots \ldots(2.5) \\
& \mathrm{n}=\text { kecepatan poros generator }(\mathrm{RPM})
\end{aligned}
$$

- Dimensi-dimensi sudu dapat dihitung dengan persamaan-persamaan berikut (1)

Lebar sudu :

$$
\mathrm{B}=(2,5 \sim 3,2) \mathrm{d}_{\mathrm{n}} \ldots \ldots . .(2.6)
$$

Panjang sudu

$\mathrm{L}=(2,1 \sim 2,7) \mathrm{d}_{\mathrm{n}}$

Lebar bukaan sudu : $M=1,2 \cdot \mathrm{d}_{\mathrm{n}}$

Kedalaman sudu : $\quad C=0,9 \cdot d_{n}$
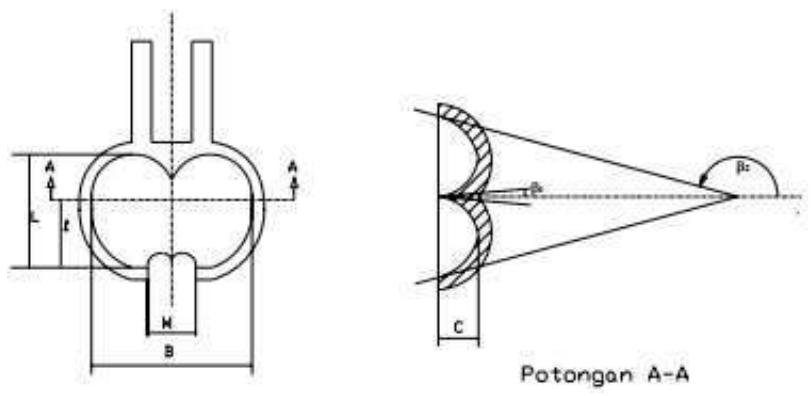

Gambar 8. Dimensi sudu turbin pelton

- Daya input system atau daya hidraulis (Erinofiardi et al., 2017)) :

$$
\mathrm{P}_{\mathrm{h}}=\rho \times \mathrm{g} \times \mathrm{H} \times \mathrm{Q}
$$

Dimana : $\quad \rho=$ massa jenis air $\left(1000 \mathrm{~kg} / \mathrm{m}^{3}\right)$

$$
\mathrm{Q}=\text { debit fluida }\left(\mathrm{m}^{3} / \mathrm{s}\right)
$$


Murtalim 1), Amir ${ }^{2)}$, Sukarman, ${ }^{3)}$ Karyadi ${ }^{4)}$, Agus Supriyanto ${ }^{5)}$, Khoirudin ${ }^{6)}$, Sugiharto ${ }^{7)}$, Toto Supriyono ${ }^{8)}$, Muhamad Abdika Mafruh ${ }^{9)}$, Fachrizal Ahmad Setiawan ${ }^{10)}$, Amar ${ }^{11)}$

Vol 6 No 1

ISSN : 2541-6995

E ISSN : 2580-5517

$$
\mathrm{H}=\text { head }(\mathrm{m})
$$

- Effisiensi Turbin (Nazari-Heris \& Mohammadi-Ivatloo, 2017)

$$
\eta_{\mathrm{t}}=\frac{\mathrm{T} \cdot \omega}{\mathrm{p} \cdot \mathrm{g} \cdot \mathrm{H} \cdot \mathrm{Q}} \mathrm{X} 100 \%
$$

Dimana :

$$
\begin{aligned}
& \mathrm{T}=\text { Torsi poros }=\mathrm{F} \mathrm{r} \quad(\mathrm{Nm}) \ldots \ldots(2 . . . \\
& \mathrm{r}: \text { Jari-jari runner }(\mathrm{m}) \\
& \quad \omega=\text { Kecepatan keliling }=\frac{2 \cdot \pi \cdot n t}{60} .
\end{aligned}
$$

- Daya listrik

$$
\mathrm{P}=\mathrm{V} \times \mathrm{I}
$$

Dimana :

$$
\begin{aligned}
& \mathrm{P}=\text { Daya Listrik, watt }(\mathrm{W}) \\
& \mathrm{V}=\text { Tegangan Listrik, Volt }(\mathrm{V}) \\
& \mathrm{I}=\text { Arus Listrik }, \text { ampere }(\mathrm{A})
\end{aligned}
$$

- Efisiensi generator adalah perbandingan antara daya output yang dihasilkan oleh generator dengan daya input yang dihasilkan oleh daya poros turbin.

$$
\begin{aligned}
& \eta_{\text {gen }}=\frac{\mathrm{P}_{\text {generator }}}{\mathrm{P}_{\text {turbin }}} \times 100 \% \\
& \eta_{\text {gen }}=\frac{\text { V.I }}{\text { Pturbin }_{\text {tur }}} \times 100 \% \\
& \mathrm{I}=\text { Kuat arus (Ampere) }
\end{aligned}
$$

- Effisiensi sistem $\left(\eta_{\text {sis }}\right)$

$$
\eta_{\text {sis }}=\frac{\text { Pgen }}{P_{h}} \times 100 \% \ldots \ldots(2.17)
$$


Murtalim ${ }^{1)}$, Amir ${ }^{2)}$, Sukarman, ${ }^{3)}$ Karyadi ${ }^{4)}$, Agus Supriyanto ${ }^{5)}$, Khoirudin ${ }^{6)}$, Sugiharto ${ }^{7)}$, Toto Supriyono ${ }^{8)}$, Muhamad Abdika Mafruh ${ }^{9)}$, Fachrizal Ahmad Setiawan ${ }^{10)}$, Amar ${ }^{11)}$

Vol 6 No 1

ISSN : 2541-6995

E ISSN : 2580-5517

Dimana : $\quad$ Pgen $=$ Daya listrik yang dihasilakan generator $($ watt $)$

$\mathrm{P}_{\mathrm{h}} \quad$ = Daya input system atau daya hidraulis (watt)

\section{HASIL PENELITIAN}

Tabel 2. Variabel hasil pengujian dan pengukuran

\begin{tabular}{|c|c|c|c|c|c|c|c|c|}
\hline \multirow{2}{*}{ No } & \multirow{2}{*}{$\begin{array}{c}\text { Diameter } \\
\text { nosel }\end{array}$} & \multirow{2}{*}{ Posisi } & \multirow{2}{*}{$\begin{array}{c}\text { Jumlah } \\
\text { nozel } \\
\end{array}$} & \multicolumn{2}{|c|}{ Putaran pully (RPM) } & \multicolumn{3}{|c|}{ Generator } \\
\hline & & & & Turbin & Generator & V (Volt) & I (ampere) & Daya Listrik (watt) \\
\hline 1 & \multirow{3}{*}{6} & Bawah & 1 & 184 & 409 & 5,9 & 0,2 & 1,0 \\
\hline 2 & & Atas & 1 & 390 & 919 & 18,5 & 0,5 & 8,3 \\
\hline 3 & & Bawah dan atas & 2 & 349 & 775 & 14,5 & 0,5 & 6,6 \\
\hline 4 & \multirow{3}{*}{9} & Bawah & 1 & 201 & 449 & 9,7 & 0,2 & 1,5 \\
\hline 5 & & atas & 1 & 423 & 941 & 21,6 & 0,5 & 11,7 \\
\hline 6 & & Bawah dan atas & 2 & 309 & 555 & 5,9 & 0,3 & 1,8 \\
\hline
\end{tabular}

Tabel : 3. Hasil perhitungan menggunakan persamaan menghasilan variable sebagai

\begin{tabular}{|c|c|c|c|c|c|c|}
\hline \multirow{3}{*}{ Variabel } & \multicolumn{3}{|c|}{$\mathrm{d}_{\mathrm{n}}($ diameter nozel $6 \mathrm{~mm})$} & \multicolumn{3}{|c|}{$\mathrm{d}_{\mathrm{n}}($ diameter nozel $9 \mathrm{~mm})$} \\
\hline & \multicolumn{3}{|c|}{ Posisi dan jumlah Nozel } & \multicolumn{3}{|c|}{ Posisi dan jumlah Nozel } \\
\hline & 1. Nozel (bawah) & 2. Nozel (atas) & 3. Dua Nozel & 1. Nozel (bawah) & 2. Nozel (atas) & 3. Dua Nozel \\
\hline $\operatorname{At~}\left(\mathrm{m}^{2}\right)$ & 0,000028 & 0,000028 & 0,000028 & 0,000064 & 0,000064 & 0,000064 \\
\hline $\mathrm{Vt}(\mathrm{m} / \mathrm{s})$ & 15,92 & 14,74 & 23,59 & 9,96 & 9,96 & 13,11 \\
\hline $\mathrm{Q}\left(\mathrm{m}^{3} / \mathrm{s}\right)$ & 0,000450 & 0,000417 & 0,000667 & 0,000633 & 0,000633 & 0,000833 \\
\hline Head Pompa (m) & 12 & 12 & 9 & 11 & 11 & 9 \\
\hline $\mathrm{u}_{1}(\mathrm{rad} / \mathrm{s})$ & 0,48 & 1,02 & 0,91 & 0,53 & 1,11 & 0,81 \\
\hline $\mathrm{m}(\mathrm{kg})$ & 2,40 & 3,50 & 2,60 & 2,30 & 3,00 & 2,70 \\
\hline $\mathrm{F}_{\mathrm{t}}(\mathrm{N})$ & 23,54 & 34,34 & 25,51 & 22,56 & 29,43 & 26,49 \\
\hline n (RPM) & 184 & 390 & 349 & 201 & 423 & 309 \\
\hline $\mathrm{T}(\mathrm{Nm})$ & 1,2 & 1,7 & 1,3 & 1,1 & 1,5 & 1,3 \\
\hline$\omega(\mathrm{rad} / \mathrm{s})$ & 19,3 & 40,9 & 36,5 & 21,0 & 44,3 & 32,4 \\
\hline Daya input $\left(\mathrm{P}_{\text {in }}\right)$, watt & 53,0 & 49,1 & 58,9 & 68,3 & 68,3 & 73,6 \\
\hline Daya turbin $\left(\mathrm{P}_{\mathrm{t}}\right)$, watt & 22,7 & 70,1 & 46,6 & 23,7 & 65,2 & 42,9 \\
\hline Effisiensi turbin $\left(\eta_{t}\right), \%$ & 42,9 & 43,0 & 79,1 & 34,7 & 95,4 & 58,3 \\
\hline Daya generator $\left(\mathrm{P}_{\text {gen }}\right)$, watt & 1,0 & 8,3 & 6,6 & 1,5 & 11,7 & 1,8 \\
\hline Effisiensi generator $\left(\eta_{\text {gen }}\right), \%$ & 4,5 & 11,9 & 14,2 & 6,3 & 17,9 & 4,2 \\
\hline Effisiensi sistem $\left(\eta_{\text {sis }}\right), \%$ & 1,9 & 16,9 & 11,3 & 2,2 & 17,1 & 2,5 \\
\hline
\end{tabular}


Murtalim 1), Amir ${ }^{2)}$, Sukarman, ${ }^{3)}$ Karyadi ${ }^{4)}$, Agus Supriyanto ${ }^{5)}$, Khoirudin ${ }^{6)}$, Sugiharto ${ }^{7)}$, Toto Supriyono ${ }^{8)}$, Muhamad Abdika Mafruh ${ }^{9)}$, Fachrizal Ahmad Setiawan ${ }^{10)}$, Amar ${ }^{11)}$

Vol 6 No 1

ISSN : 2541-6995

E ISSN : 2580-5517

\section{PEMBAHASAN}

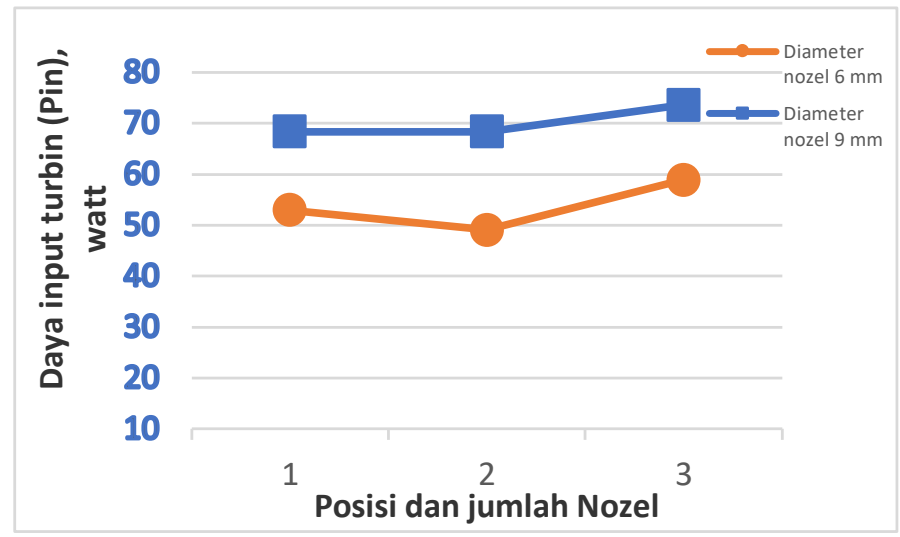

Gambar 9. Hubungan antara variasi jumlah, posisi dan diameter nosel terhadap daya inpu Turbin $\mathrm{P}_{\text {in }}$

Dapat disimpulkan dari Gambar 9. diatas, daya terbesar terjadi pada nosel dengan diameter $9 \mathrm{~mm}$ dengan dua nosel yang ada di posisi atas dan bawah,. Hal Ini terjadi karena debit air yang dikeluarkan oleh nosel yang berdiameter besar akan lebih besar pula luas penampang dari nosel tersebut.

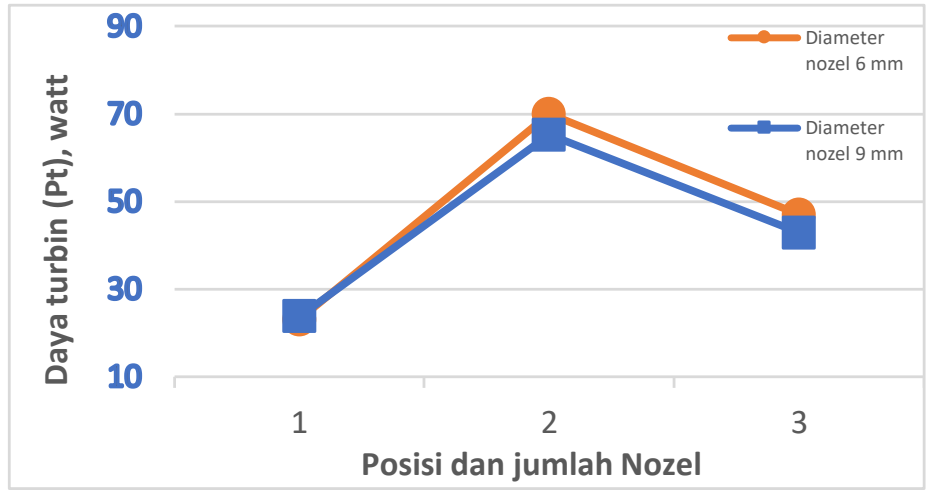

Gambar 10. Hubungan antara variasi jumlah, posisi dan diameter nosel terhadap daya $\mathrm{P}_{\text {turbin }}$

Dapat disimpulkan dari Gamabr 10 diatas, daya terbesar terjadi pada nosel dengan diameter $6 \mathrm{~mm}$ dan posisi nosel diatas sudu,. Hal Ini terjadi karena gaya air yang menumbuk sudu $(\mathrm{F})$ nilai terbesar hal tersebut dipengaruhi oleh kecepatan realatif $\left(\mathrm{V}_{\mathrm{r}}\right)$ 
Murtalim 1), Amir ${ }^{2)}$, Sukarman, ${ }^{3)}$ Karyadi ${ }^{4)}$, Agus Supriyanto ${ }^{5)}$, Khoirudin ${ }^{6)}$, Sugiharto ${ }^{7)}$, Toto Supriyono ${ }^{8)}$, Muhamad Abdika Mafruh ${ }^{9)}$, Fachrizal Ahmad Setiawan ${ }^{10)}$, Amar ${ }^{11)}$

Vol 6 No 1

ISSN : 2541-6995

E ISSN : 2580-5517

yakni selisih antara kecepatan air keluar nosel $\left(\mathrm{V}_{1}\right)$ dengan kecepatan keliling (u). Sehingga pada torsi $(\mathrm{T})$ dan daya Turbin $\left(\mathrm{P}_{\mathrm{t}}\right)$ nilainya menjadi besar

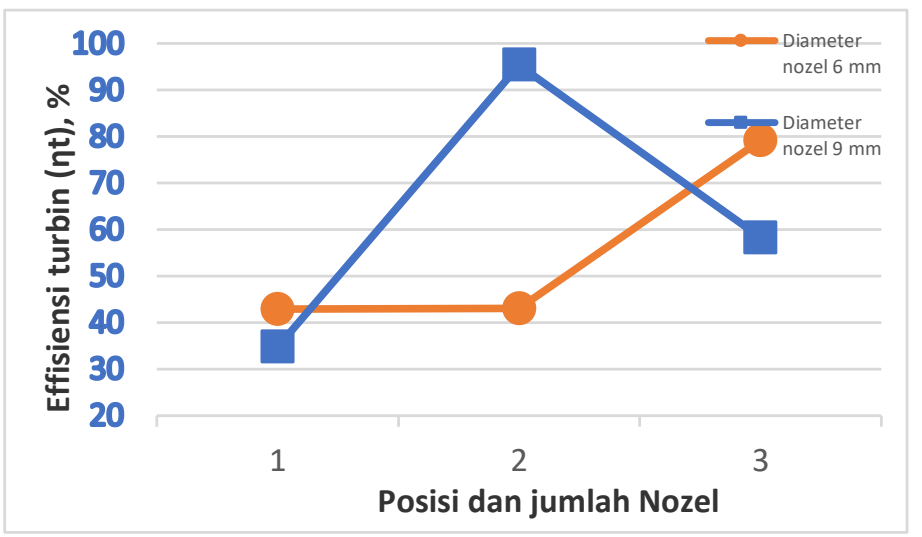

Gambar 11. Hubungan antara variasi jumlah, posisi dan diameter nosel terhadap daya effisiensi turbin $\left(\eta_{t}\right)$,

Dapat dilihat pada Gambar 11. Effisiensi terbesar terjadi pada nosel $9 \mathrm{~mm}$ dengan posisi nosel diatas sudu turbin $\mathrm{Hal}$ ini disebabkan oleh antara tingginya rasio antara daya output sebagai daya Turbin $\left(\mathrm{P}_{\mathrm{t}}\right)$ dengan daya air sebagai daya input

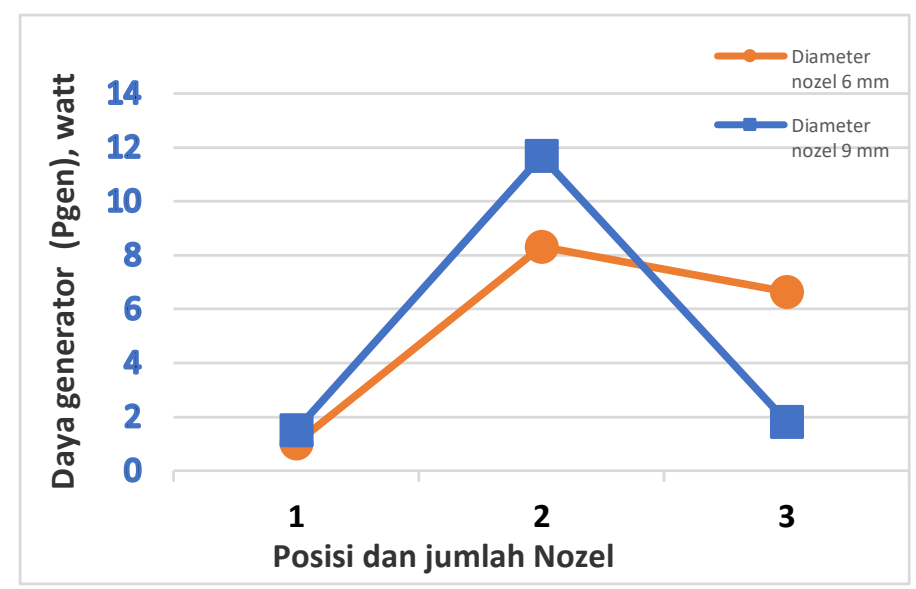

Gambar 12. Hubungan antara variasi jumlah, posisi dan diameter nosel terhadap daya generator $\left(\mathrm{P}_{\text {gen }}\right)$,

Dapat disimpulkan dari gambar 12 diatas, bahwa dayagenerator $\left(\mathrm{P}_{\mathrm{gen}}\right)$ terbesar didapatkan pada diameter nosel $\left(d_{n}\right) 9$ mm dengan posisi satu nosel yang berada diatas sudu turbin. Hal ini disebabkan oleh kecepatan keliling (u) pada runner yang tinggi menyebabkan 
Murtalim 1), Amir ${ }^{2)}$, Sukarman, ${ }^{3)}$ Karyadi ${ }^{4)}$, Agus Supriyanto ${ }^{5)}$, Khoirudin ${ }^{6)}$, Sugiharto ${ }^{7)}$, Toto Supriyono ${ }^{8)}$, Muhamad Abdika Mafruh ${ }^{9)}$, Fachrizal Ahmad Setiawan ${ }^{10)}$, Amar ${ }^{11)}$

Vol 6 No 1

ISSN : 2541-6995

E ISSN : 2580-5517

putaran generator jugatinggi. putaran pully pada generator tmenyebabkan beasrnya nilai tegangan yang dihasilkan.

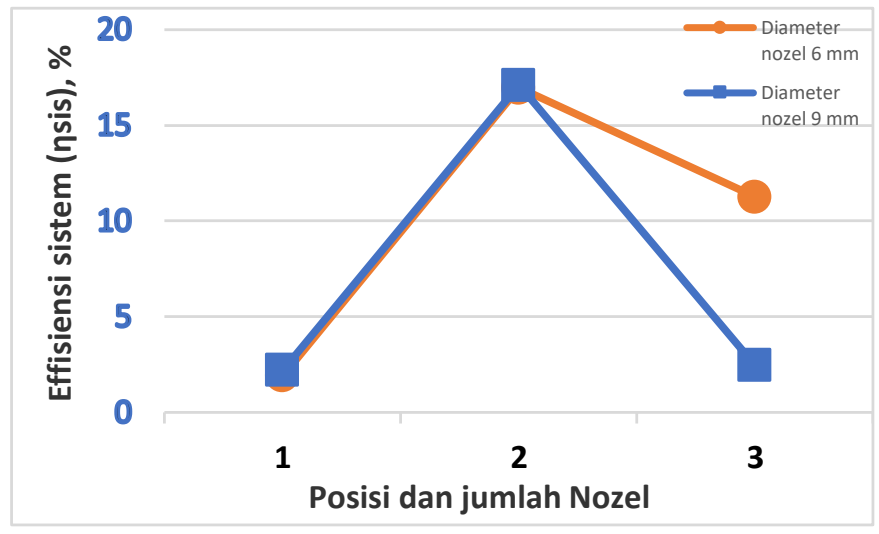

Gambar 13. Hubungan antara variasi jumlah, posisi dan diameter nosel terhadap effisiensi sistem turbin pelton $\left(\eta_{\text {sis }}\right)$

Dapat dilihat pada Gambar 13. Effisiensi terbesar terjadi pada nosel $9 \mathrm{~mm}$ dengan posisi nosel diatas sudu turbin hal ini disebabkan oleh tingginya rasio antara daya generator $\left(\mathrm{P}_{\text {gen }}\right)$ dengan daya Turbin $\left(\mathrm{P}_{\mathrm{in}}\right)$ sebagai daya input air yang diberikan kepada turbin

\section{KESIMPULAN DAN IMPLIKASI}

Variasi diameter, posisi, dan jumlah nosel pada pengujian turbin pelton ini berpengaruh terhadap daya dan effisiensi. Untuk variasi diameter nosel $\left(d_{n}\right)$ yang digunakan bisa di ketahui bahwa penggunaan diameter nosel yang besar $9 \mathrm{~mm}$ telah meningkatkan nilai daya input $\left(\mathrm{P}_{\mathrm{in}}\right)$, effisiensi turbin $\left(\eta_{\mathrm{t}}\right)$, dan daya generator $\left(\mathrm{P}_{\text {gen }}\right)$. Variasi posisi nozel yang sangat berengaruh besar adalah apabila nosel ditempatkan diatas sudu turbin, hal ini disebabkan oleh kecepatan realatif $\left(\mathrm{V}_{\mathrm{r}}\right)$ yakni selisih antara kecepatan air keluar nosel $\left(\mathrm{V}_{1}\right)$ dengan kecepatan keliling $(\mathrm{u})$. Sehingga pada torsi $(\mathrm{T})$ dan daya Turbin $\left(\mathrm{P}_{\mathrm{t}}\right)$ nilainya menjadi besar. Untuk jumlah nozel yang besar yaitu 2 buah nozel hanya berpengaruh terhadap daya input turbin yang lebih besar, karena nilai debit aliran dan (Q), luas penampang jet diameter $\left(A_{t}\right)$ nozel akan bertambah besar juga. Penggunaan dua noozel 
Murtalim ${ }^{1)}$, Amir ${ }^{2)}$, Sukarman, ${ }^{3)}$ Karyadi ${ }^{4)}$, Agus Supriyanto ${ }^{5)}$, Khoirudin ${ }^{6)}$, Sugiharto ${ }^{7)}$, Toto Supriyono ${ }^{8)}$, Muhamad Abdika Mafruh ${ }^{9)}$, Fachrizal Ahmad Setiawan ${ }^{10)}$, Amar ${ }^{11)}$

Vol 6 No 1

ISSN : 2541-6995

E ISSN : 2580-5517

turbin tidak begitu berpengaruh dalam upaya peningkatan effiensi turbin $\left(\eta_{t}\right)$, effisiensi ggenerator $\left(\eta_{\text {gen }}\right)$, dan efisiensi sistem $\left(\eta_{\text {sis }}\right)$ turbin pelton.

\section{DAFTAR RUJUKAN}

Aggidis, G. A., \& Židonis, A. (2014). Hydro turbine prototype testing and generation of performance curves: Fully automated approach. Renewable Energy, 71, 433-441. https://doi.org/10.1016/j.renene.2014.05.043

Ebhota, W. S., \& Inambao, F. (2016). Design basics of a small hydro turbine plant for capacity building in Sub-Saharan Africa. African Journal of Science, Technology, Innovation and Development, 8(1), 111-120. https://doi.org/10.1080/20421338.2015.1128039

Erinofiardi, Nuramal, A., Bismantolo, P., Date, A., Akbarzadeh, A., Mainil, A. K., \& Suryono, A. F. (2017). Experimental Study of Screw Turbine Performance based on Different Angle of Inclination. Energy Procedia, 110(December 2016), 8-13. https://doi.org/10.1016/j.egypro.2017.03.094

Ihfazh, N., Waluyo, \& Syahrial. (2013). Penerapan dan Analisis Pembangkit Listrik Tenaga Pikohidro dengan Turbin Propeller Open Flume TC 60 dan Generator Sinkron Satu Fasa 100 VA di UPI Bandung. Jurnal Reka Elkomika, 1(4), 328338.

Kurniawan.Y. (2017). Pengaruh Jarak dan Posisi Nozzle Terhadap Daya Turbin Pelton. Jurnal Keteknikan Pertanian, Vol. 5 No., 12-26.

Nazari-Heris, M., \& Mohammadi-Ivatloo, B. (2017). Design of Small Hydro Generation Systems. In Distributed Generation Systems: Design, Operation and Grid Integration. Elsevier Inc. https://doi.org/10.1016/B978-0-12804208-3.00006-6

Pasalli, Y. R., \& Rehiara, A. B. (2014). Design Planning of Micro-hydro Power Plant in Hink River. Procedia Environmental Sciences, 20, 55-63. https://doi.org/10.1016/j.proenv.2014.03.009

Poea, C., Soplanit, G. ., \& Rantung, J. (2013). Pembangkit Listrik Di Desa Kali Kecamatan Pineleng Dengan Head 12 Meter. Teknik Mesin, 1-9.

Rameez, P. V., \& Prince, M. G. (2015). Design and performance analysis of thermocompressor. International Journal of Applied Engineering Research, 10(13), 11348-11351.

Singh, P. M., Chen, Z., \& Choi, Y. Do. (2017). Hydraulic design and performance analysis on a small pump-turbine system for ocean renewable energy storage system. Journal of Mechanical Science and Technology, 31(11), 5089-5097. https://doi.org/10.1007/s12206-017-1002-7

Subekti, R. A., \& Susatyo, A. (2015). Pengujian prototipe turbin head sangat rendah pada suatu saluran aliran air. Pusat Penelitian Tenaga Listrik Dan Mekatronik, LIPI, Bandung, 2.

Sugiri, A., Jurusan, M., Mesin, T., Teknik, F., Lampung, U., Jurusan, D., Mesin, T., Teknik, F., Lampung, U., \& Belakang, L. (2013). Jurnal FEMA, Volume 1 , Nomor 1 , Januari 2013 STUDI POTENSI PEMBANGKIT LISTRIK TENAGA MIKROHIDRO ( PLTMH ) DI SUNGAI CIKAWAT DESA TALANG MULIA KECAMATAN. 1, 48-54. 
Murtalim 1), Amir ${ }^{2)}$, Sukarman, ${ }^{3)}$ Karyadi ${ }^{4)}$, Agus Supriyanto ${ }^{5)}$, Khoirudin ${ }^{6)}$, Sugiharto ${ }^{7)}$, Toto Supriyono ${ }^{8)}$, Muhamad Abdika Mafruh ${ }^{9)}$, Fachrizal Ahmad Setiawan ${ }^{10)}$, Amar ${ }^{11)}$ Vol 6 No 1 ISSN : 2541-6995 E ISSN : 2580-5517

Syarif, A., Trisnaliani, L., Teknik, J., Program, K., Sarjana, S., Teknik, T., Sriwijaya, P. N., Srijaya, J., Bukit, N., \& Palembang, B. (2019). Rancang Bangun Prototipe Pembangkit Listrik Tenaga Mikro Hidro (PLTMH) Turbin Pelton The Design Of Pelton Turbine Micro Hydro Power. Kinetika, 8(2017), $1-6$.

Turbin, P., \& Di, P. (2015). KAJI EKSPERIMENTAL PENGARUH VARIASI DIAMETER NOZZEL DAN JUMLAH SUDU TERHADAP DAYA DAN EFFISIENSI PADA. 1(1).

Zhang, Z. (2016). Pelton turbines. In Pelton Turbines. https://doi.org/10.1007/9783-319-31909-4

Židonis, A., \& Aggidis, G. A. (2015). State of the art in numerical modelling of Pelton turbines. Renewable and Sustainable Energy Reviews, 45, 135-144. https://doi.org/10.1016/j.rser.2015.01.037

Židonis, A., \& Aggidis, G. A. (2016). Pelton turbine: Identifying the optimum number of buckets using CFD. Journal of Hydrodynamics, 28(1), 75-83. https://doi.org/10.1016/S1001-6058(16)60609-1 